\title{
Pengembangan Modul Discon Sains Di Sekolah Dasar
}

\author{
Azizah ${ }^{1}$, Puji Winarti ${ }^{2}$ \\ ${ }^{12}$ Prodi PGSD, FKIP, Universitas Darul Ulum Islamic Centre Sudirman Ungaran \\ 1azizaathalib@gmail.com \\ 2pujiwinartirulian@gmail.com
}

\begin{abstract}
ABSTRAK
Penelitian ini yaitu bertujuan (1) mendeskripsikan karakteristik modul Discon pada pembelajaran Praktikum Sains di Kelas IV sekolah dasar; (2) mengetahui kevalidan, kepraktisan, dan efektivitas modul Discon Sains di Kelas IV sekolah dasar. Penelitian ini merupakan jenis penelitian dan pengembangan (Research and Development). Penelitian ini bertujuan untuk mengembangkan produk pendidikan yaitu berupa modul yang dapat digunakan dalam pembelajaran Sains. Model penelitian yang digunakan diadopsi dari model R\&D tiga fase dari Gravemeijer \& Cobb yaitu fase penelitian awal, fase pengembangan dan fase penilaian. Uji keefektifan modul dianalisis menggunakan n-gain. Hasil penelitian menunjukan nilai validitas modul sebesar 50,5 dengan kriteria valid. Uji kepraktisan modul yang memperoleh hasil sebesar 63,8 dengan kriteria sangat praktis. Uji keefektifan menggunakan n-gain diperoleh nilai sebesar 0,71 dengan kategori tinggi. Dari hasil penelitian dapat disimpulkan bahwa Modul Discon Sains di Kelas IV sekolah dasar yang dikembangkan telah memenuhi keriteria valid, praktis, dan efektif sehingga dapat digunakan sebagai salah satu bahan ajar dalam pembelajaran Sains di sekolah dasar.
\end{abstract}

Kata kunci: Modul Discon, Sains

\section{PENDAHULUAN}

Secara historis, sains memiliki dua aspek: pertama adalah a body of knowledge atau sebagai tubuh pengetahuan dan kedua $a$ way of working atau cara kerja. Kedua aspek tersebut saling terhubung dan tak terpisahkan. Setiap kali para ilmuwan bekerja, mereka mencari tahu tentang dunia menggunakan metode ilmiah. Sama halnya, para siswa juga mencari tahu tentang dunia menggunakan metode dasar yang sama. Meskipun tingkat kecanggihan tugas berbeda dan alat yang digunakan juga berbeda, pada dasarnya baik para ilmuwan maupun siswa mencari tahu tentang dunia menggunakan proses yang sama. Salah satu tujuan utama dari pendidikan sains adalah untuk mengembangkan pemahaman siswa melalui penggunaan pendekatan ilmiah (Ward, Roden, Hewlett, \& Foreman, 2008).

Sains menekankan pada pemberian pengalaman langsung baik menggunakan investigasi, eksperimen maupun observasi ataupun yang lainnya, sehingga menghasilkan data yang didapatkan benarbenar valid dan bisa dipertanggungjawabkan (Azizah \& Winarti, 2016). Pembelajaran Sains menuntut siswa harus dapat menggunakan metode-metode ilmiah yaitu yang meliputi keterampilan proses yang dibarengi dengan sikap sains.
Keterampilan proses sains meliputi mengamati, mengukur, menarik kesimpulan, mengendalikan variabel, merumuskan hipotesis, membuat grafik, definisi operasional dalam melakukan eksperimen (Sappe, 2013).

Pengajaran sains yang baik memiliki banyak kesamaan dengan pengajaran yang baik pada umumnya. Pembelajaran yang dirancang dengan baik adalah pembelajaran yang didasarkan pada penilaian yang tepat dari pengetahuan dan pemahaman anak sebelumnya. Oleh karena itu, sebelum pembelajaran dimulai, seorang guru harus dapat memilih strategi pengajaran yang tepat.

McNaughton dan Williams (Gillespie \& Gillespie, 2007) dalam bukunya "Teaching Young Children" menetapkan berbagai teknik mengajar umum, yang dapat diterapkan pada ilmu pengajaran. Salah satu aspek yang sangat penting dari pengajaran sains adalah pertanyaan. Sifat dan struktur dari pertanyaan sangat penting jika guru ingin mendapatkan yang terbaik dari pertanyaan yang mereka ajukan dan mendorong anak-anak untuk membangun pertanyaannya sendiri.

McNaughton dan Williams mengatakan bahwa guru harus dapat merencanakan berbagai teknik bertanya yang dapat menstimulasi keterampilan berpikir tingkat tinggi anak-anak. Beberapa hal yang menjadi pertimbangan ketika guru memilih 
pertanyaan yaitu (1) apakah pertanyaan yang diajukan sudah sesuai; (2) bagaimana menyusun pertanyaan, pikirkan panjangnya jawaban dan kosakata yang digunakan; (3) apakah pertanyaan tersebut diarahkan pada satu anak, kelompok atau diminta untuk semua siswa; (4) jenis jawaban yang diantisipasi dan tanggapan terhadap jawaban yang akan memancing anak-anak untuk bertanya lagi.

Pembelajaran investigasi anak-anak adalah proses yang kompleks. Guru perlu mendukung pembelajaran dengan berbagai cara, termasuk mengembangkan pertanyaan dan kemauan untuk terlibat dalam penyelidikan terbuka. Untuk membantu mengembangkan keterampilan investigasi, penting untuk memilih metode yang tepat dalam mengajar.

Metode

discovery learning

memadukan teknik-teknik yang berpusat pada siswa. Piaget dan ahli konstruktivisme lainnya menyebutkan kesiapan mental untuk menginternalisasi konsep, yaitu pada tahap perkembangan mental siswa, menghubungkan pengetahuan sebelumnya dan mengkonstruksi konsep sains, dan kemampuan siswa untuk terlibat dalam pembelajaran penemuan, baik bebas atau dibimbing. Siswa hanya dapat menginternalisasi konsep-konsep yang secara mental mereka "siap". Oleh karena itu semakin mudah usia siswa, maka guru harus semakin menyajikan pengalaman agar mendapatkan informasi baru (pengetahuan sebelumnya) dan membimbing mereka untuk membangun konsep mereka sendiri. Semakin tua usia siswa, semakin sedikit peran guru. Siswa akan semakin banyak bekerja bersama guru yang berperan sebagai fasilitator, narasumber, pendorong, dan pembimbing. (Carin, 1993).

Pembelajaran Discovery learning mencoba untuk membantu siswa untuk belajar dan memperoleh pengetahuan serta membangun konsep yang unik mereka sendiri karena mereka menemukannya sendiri. Discovery learning tidak terbatas untuk menemukan sesuatu yang benar-benar baru bagi dunia seperti penemuan (televisi) atau teori (pandangan tentang alam semesta). Tetapi terkait dengan siswa secara internal dapat menata ulang pengetahuan yang mereka miliki sehingga mereka dapat melampaui fakta-fakta belaka untuk membentuk konsep baru bagi mereka. Discovery learning melibatkan siswa menemukan makna, hubungan, dan struktur ide mereka sendiri (Carin, 1993).

Guru yang berperan sebagai seorang fasilitator dalam pembelajaran Sains dengan menggunakan metode discovery leraning harus dapat mengakomodir semua keperluan siswa. Guru harus menyiapkan peralatan, buku, modul, LKS atau lingkungan agar siswa dapat menemukan ide, konsep, atau pengetahuan baru.

Sebagian besar guru dalam pembelajaran Sains di sekolah dasar saat ini telah melakukan usaha-usaha yang maksimal agar kompetensi pembelajaran tercapai. Mereka telah menggunakan variasi metode yang disesuaikan dengan karakteristik materi pembelajaran serta penggunaan alat peraga dalam beberapa materi. Dalam penggunaan sumber belajar barupa bahan ajar cetak, guru hanya terpaku pada "Buku Guru" atau buku paket yang telah disiapkan pemerintah. Dalam buku paket tesebut esensi dari setiap materi disajikan terbatas. Selain itu, khusus untuk kegiatan "Hand-on" disajikan satu contoh kegiatan "praktikum" untuk satu materi. Contoh kegiatan praktikum yang disajikan tersebut memuat alat dan bahan yang digunakan serta prosedur percobaan. Dengan model petunjuk praktikum seperti itu, maka praktikum yang dilakukan oleh siswa hanya sebatas memperkuat pemahaman siswa akan materi yang dipelajari. Mereka tidak dapat mengorganisasi atau menemukan pemahaman sendiri. Fenomena di atas merupakan hasil observasi yang dilakukan dibeberapa SD yang berada di Kabupaten Semarang.

Untuk memecahkan permasalahan tersebut, maka salah satu solusi yang akan ditawarkan yaitu dengan menambahkan referensi bagi guru dan siswa. Salah satunya yaitu dengan modul belajar. Dengan modul ini diharapkan peran guru sebagai fasilitator dalam pembelajaran semakin kuat.

Modul merupakan salah satu media pembelajaran yang dapat digunakan dalam pembelajaran Sains. Dalam buku Pedoman Umum Pengembangan Bahan Ajar yang diterbitkan oleh Depdiknas (Kemendikbud, 2016) , modul diartikan sebagai buku yang ditulis dengan tujuan agar peserta didik dapat belajar mandiri tanpa atau bimbingan guru. Sesuai dengan karakteristiknya sebagai media pembelajaran mandiri, sehingga cocok digunakan dalam pembelajaran Sains yang menggunakan metode discovery learning.

Melihat begitu pentingnya media pembelajaran dalam pembelajaran Sains, peneliti sangat tertarik untuk mengembangkan modul praktikum Sains untuk dipelajari oleh siswa secara mandiri. Dengan modul ini diharapkan siswa dapat menguasai konsep 
Sains melalui belajar menemukan sendiri (discovery learning) sehingga pembelajaran menjadi lebih bermakna. Berdasarkan uraian di atas maka peneliti mengambil judul "Pengembangan Modul Discon (Discovery Learning) Pada Pembelajaran Sains Di IV Sekolah Dasar".

Rumusan masalah dalam penelitian ini yaitu (1) bagaimana mengembangkan modul Discon Sains di Kelas IV sekolah dasar?; (2) Apakah pengembangan modul Discon Sains di Kelas IV sekolah dasar memenuhi kriteria Valid, Praktis dan Efektif?. Berdasarkan rumusan masalah tersebut, maka tujuan penelitian ini yaitu (1) mendeskripsikan karakteristik modul Discon Sains di Kelas IV sekolah dasar; (2) mengetahui kevalidan, kepraktisan, dan efektivitas modul Discon Sains di Kelas IV sekolah dasar. Hipotesis dalam penelitian ini yaitu modul Discon sains di Kelas IV sekolah dasar yang dikembangkan memenuhi kriteria valid, praktis dan efektif.

\section{Kelebihan Metode Discovery Learning}

Jerome Bruner dalam (Carin, 1993) , mengemukakan 4 manfaat dari penggunaan metode Discovery learning yaitu:

1. Potensi intelektual

Menurut Bruner, Dengan kepampuan atau potensi intelektual, seorang anak dapat mengembangkan pemikirannya hanya jika dia menggunakan pikirannya tersebut. Bruner menekankan bahwa satu-satunya cara untuk belajar menggunakan metode discovery learning adalah dengan memberikan kesempatan kepada siswa untuk menemukannya sendiri. Melalui discovery learning siswa dapat siswa perlahan-lahan belajar bagaimana mengatur dan melaksanakan investigasi secara independen. Salah satu hasil terbesar dari pendekatan discovery learning adalah bahwa metode discovery learning membantu retensi memori yang lebih baik dan dapat mengaplikasikan untuk situasi baru. Hal ini diperkuat oleh hasil penelitian Robet Glaser dalam (Carin, 1993), yaitu pengetahuan yang diperoleh dari hasil penyelesaian masalah lebih mudah diaplikasikan pada situasi yang baru.

2. Motivasi intrinsik dan bukan ekstrinsik

Discovery Learning membantu siswa menjadi lebih otonom, mandiri, dan bertanggung jawab untuk pembelajaran yang mereka lakukan. Siswa akan menjadi lebih termotivasi ketika mereka belajar dengan menemukan sesuatu sendiri, daripada hanya mendengar tentang hal itu. Mereka belajar untuk melaksanakan kegiatan mereka dengan kebebasaan yang diberikan. Bentuk kebebasan ini merupakan bentuk penghargaan bagi anak dalam penemuan itu sendiri. Dengan kebebasan itu, anak-anak belajar memanipulasi lingkungan mereka lebih aktif. Kepuasan bagi mereka adalah jika dapat memecahkan masalah sendiri. Bruner percaya, sebagai konsekuensi dari suksesnya kecerdasan intelektual adalah penghargaan intrinsik atau memuaskan diri. Beberapa hasil penelitian menunjukan bahwa motivasi ekstrinsik lebih efisien dalam hal jumlah relatif waktu yang dihabiskan dalam mempelajari tugas, keterampilan, atau pengetahuan. Namun, informasi yang dipelajari oleh motivasi intrinsik dipertahankan lebih lama. J. Richard Suchman dalam (Carin, 1993) mengemukakan bahwa pembelajaran dengan pendekatan discovery learning memberikan suasana yang tidak menghukum dan menstimulasi di mana anak-anak terlibat dalam pembelajaran karena itu menyenangkan, menarik, dan memuaskan diri. Dalam pendekatan ini, guru, bertindak sebagai fasilitator dan memberikan siswa lingkungan yang responsif terhadap kebutuhan siswa. Cobalah untuk menghapus pandangan tentang guru sebagai penyalur informasi dan penghargaan. Berikan siswa kesempatan untuk mencoba berbagai hal tanpa takut akan penghargaan atau hukuman (eksternal) guru.

3. Mempelajari heuristik penemuan

Heuristik memiliki aspek yang mirip dengan proses metakognisi. Meta berasal dari bahasa Yunani dan berarti "setelah, di tengah, dan di atas dan di atas". Metakognisi fokus pada keterampilan mental dan proses yang digunakan dalam situasi masalah tertentu. Robert Sternberg dalam (Carin, 1993) menjelaskan keterampilan dan proses metakognisi sebagai keterampilan metakognitif yang digunakan dalam menemukan dan menggambarkan masalah, perencanaan apa yang harus dilakukan dalam mencari solusi permasalahan, mengimplementasikan rencana, dan memantau dan menilai tindakan. John Barell menegaskan 
pengetahuan tentang kapan menggunakan strategi adalah bentuk penting dari metakognisi. Tugas guru adalah membantu siswa belajar menemukan caranya sendiri atas permasalahan yang ada. Salah satu cara penting adalah membimbing mereka dalam memproses informasi baru.

4. Konservasi memori

Para ahli psikolog menyebut konservasi memori dengan istilah "Transfer of training". Transfer of learning merupakan upaya mengingat kembali pengalaman atau kebiasaan yang telah dilakukan sebelumnya, untuk melakukan sesuatu yang baru. Agar transfer of training menjadi paling efektif, maka 2 faktor yang harus bekerja yaitu (1) Transfer of training yang positif akan terjadi jika ada kesamaan antara subjek. Semakin dekat kemiripan subjek, semakin baik peluang transfer of training; (2) Transfer of training yang positif akan terjadi jika ada pembelajaran pengetahuan, konsep, prinsip, atau teknik dalam situasi pertama yang dapat bermanfaat diterapkan pada situasi kedua. Oleh karena itu, guru menginginkan siswa menjadi pemecah masalah, belajar dengan penemuan, dan melakukan sesuatu untuk diri mereka sendiri, maka guru harus memberikan latihan dalam semua hal ini. Semakin banyak mereka memecahkan masalah dengan bimbingan guru, semakin besar kemungkinan siswa dapat memecahkan masalah pada situasi atau masalah baru.

\section{METODE PENELITIAN}

Penelitian ini merupakan jenis

penelitian dan pengembangan (Research and

Development). Penelitian ini bertujuan untuk mengembangkan produk pendidikan yaitu berupa modul yang dapat digunakan dalam pembelajaran Sains. Model penelitian yang digunakan diadopsi dari model R\&D tiga fase dari Gravemeijer \& Cobb (Sani, Manurung, Suswanto, \& Sudiran, 2018).

Desain pengembangan produk dalam tiga fase $R \& D$, yaitu:
1. Fase penelitian awal,
Penelitian analisis

kebutuhan dan konteks, reviu literatur, serta pengembangan kerangka teori dan kerangka konseptual untuk studi. Peneliti mengidentifikasi permasalahan pembelajaran Sains di SD dengan melakukan observasi ke beberapa sekolah. Kemudian peneliti melakukan studi literatur pada artikel hasil penelitian terkait dengan permasalahan sejenis. Studi literatur juga dilakukan untuk mengetahui desain modul yang efektif, yang mencakup komponen utama atau unsur-unsur modul, struktur, urutan penyajian, evaluasi dan sebagainya.

2. Fase pengembangan, mencakup pengembangan prototipe atau intervensi yang diikuti dengan pengujian secara berkala. Tujuan pelaksanaan evaluasi pada pelaksanaan fase ini adalah untuk memperbaiki intervensi yang telah dikembangkan. Pada tahap kedua dilakukan pengembangan desain Modul Discon pada pembelajaran Sains dengan berdasarkan informasi yang diperoleh pada studi pendahuluan. Modul tersebut dimintakan untuk direviu oleh beberapa ahli untuk memperoleh masukan perbaikan. Ahli yang terlibat dalam penelitian ini ada 2 orang dosen IPA yaitu (1) Bapak Ikhlasul Ardi Nugroho, S.Pd.Si., M.Pd, Dosen IPA PGSD dari Universitas Negeri Yogyakarta dan (2) Bapak Satya Eko Atmojo, M.Pd, Dosen IPA PGSD dari Universitas PGRI Yogyakarta. Aspek penilaian dalam validasi modul yaitu aspek isi materi dan aspek penyajian pembelajaran dalam modul (Daryanto, 2018).

Analisis data dari hasil validasi modul dengan menggunakan rumus:

$$
X=\frac{\text { Skor perolehan }}{\text { Skor maksimal }} x 100
$$

Hasil penilaian dalam bentuk kuantitatif tersebut, kemudian dikonversi ke dalam bentuk kualitatif untuk mendapatkan kriteria sesuai dengan tujuan penelitian.

Berikut disajikan tabel kriteria penilaian kualitatif.

Tabel 1. Kriteria penilaian kualitatif

\begin{tabular}{cc}
\hline Rentang & Data Kualitatif \\
\hline$X>54,6$ & Sangat Valid \\
\hline $44,2<X \leq 54,6$ & Valid \\
\hline $33,8<X \leq 44,2$ & Cukup Valid \\
\hline $23,4<X \leq 33,8$ & Kurang Valid \\
\hline$X \leq 23,4$ & Sangat kurang Valid \\
\hline
\end{tabular}


Setelah modul dinyatakan valid oleh para ahli, selanjutnya peneliti melakukan ujicoba terbatas. Jumlah sekolah yang terlibat dalam ujicoba terbatas yaitu sebanyak 3 sekolah dengan jumlah total siswa sebanyak 15 siswa. Sekolah yang terlibat dalam ujicoba terbatas ini yaitu SDN Ungaran 01, SDN Sidomulyo 03 dan SDN Kalirejo 02 Kecamatan Ungaran Timur. Desain penelitian yang digunakan pada ujicoba terbatas yaitu dengan metode eksperimen satu kelas tanpa pretes. Pengumpulan data dilakukan dengan membagikan kuesioner kepraktisan kepada setiap siswa. Siswa diminta mengisi angket tersebut setelah mereka menggunakan Modul Discon dalam Pembelajaran Praktikum Sains. Indikator kepraktisan modul Discon yaitu efektif, efesien, kreatif, menarik, dan interaktif (Alfiriani \& Hutabri, 2017). Analisis data dari hasil uji kepraktisan modul dengan menggunakan rumus seperti analisis uji validitas. Tetapi kriteria analisis data kualitatif berbeda dengan kriteria pada uji validitas. Hal ini disebabkan karena perbedaan jumlah pernyataan instrumen yang digunakan. Kriteria kepraktisan modul Discon dapat dilihat pada tabel berikut.

Tabel 2. Kriteria penilaian kualitatif

\begin{tabular}{cl}
\hline Rentang & \multicolumn{1}{c}{ Data Kualitatif } \\
\hline$X>63$ & Sangat Praktis \\
\hline $51<X \leq 63$ & Praktis \\
\hline $39<X \leq 51$ & Cukup Praktis \\
\hline $27<X \leq 39$ & Kurang Praktis \\
\hline$X \leq 27$ & Sangat kurang Praktis \\
\hline
\end{tabular}

3. Pada tahap ketiga dilakukan validasi

Modul yang dinyatakan valid dan praktis, selanjutnya diujicoba lagi untuk menghasilkan modul yang efektif digunakan dalam pembelajaran IPA. Untuk menguji keefektifan digunakan kelas yang lebih luas. Sekolah yang terlibat dalam ujicoba luas ini berjumlah 3 SD dengan 110 siswa. Sekolah tersebut yaitu SDN Ungaran 01, SDN Sidomulyo 03, dan SDN Kalirejo 02. Desain penelitiannya menggunakan metode eksperimen (one group pretes-posttest design). Tes yang digunakan berbentuk pilihan ganda. Analisis data menggunakan uji Gian ternormalisasi.

Gain ternormalisasi $(g)$

$$
=\frac{\text { skor postes }- \text { skor pretes }}{\text { skor maks }- \text { skor pretes }}
$$

Adapun kriteria tingkat capain Uji Gain dapat dilihat dalam tabel 3 berikut

Tabel 3. Kriteria penilaian kualitatif

\begin{tabular}{cc}
\hline Nilai & Kriteria \\
\hline $0,00 \leq \mathrm{N} \leq 0,30$ & Rendah \\
\hline $0,30 \leq \mathrm{N} \leq 0,70$ & Sedang \\
\hline $0,70 \leq \mathrm{N} \leq 1,00$ & Tinggi \\
\hline
\end{tabular}

\section{HASIL \& PEMBAHASAN}

Modul Discon merupakan salah satu jenis bahan ajar cetak yang disusun dengan pendekatan discovery learning. Modul Discon adalah bahan ajar mandiri yang dapat membantu siswa mempelajari IPA dengan melakukan investigasi atau penyelidikan melalui percobaan-percobaan, prediksi, analisis serta penarikan kesimpulan. Dengan modul ini, siswa dapat mengembangkan pemahamannya tentang pembelajaran IPA melalui pengetahuan baru yang mereka bangun sendiri berdasarkan langkah-langkah ilmiah. Dengan kata lain, modul ini merupakan salah satu bahan ajar siswa yang dapat digunakan dalam kegiatan praktikum IPA.

Berikut langkah-langkah pengembangan modul Discon Sains.

1. Fase penelitian awal.

Fase ini dilakukan dengan kegiatan studi pendahuluan dan studi literatur. Studi pendahuluan yaitu mencakup analisis kebutuhan. Dari studi pendahuluan didapatkan bahwa kegiatan praktikum Sains selama ini dilakukan oleh guru dan siswa dengan bantuan LKS (Lembar Kerja Siswa) dan buku paket. Komponen terkait kegiatan praktikum dalam LKS dan buku tersebut 
meliputi judul percobaan, alat dan bahan, serta prosedur percobaan. Melalui komponen ini, maka dapat dikatakan kegiatan praktikum yang dilakukan oleh guru dan siswa bersifat pemantapan materi. Penjelasan materi oleh guru, kemudian didemonstrasikan dengan menggunakan panduan LKS dan buku paket. Selanjutnya melakukan revie literatur meliputi analisis kurikulum yang diterapkan di sekolah dasar dan desain modul yang efektif digunakan dalam pembelajaran sesuai kompetensi yang ada dalam kurikulum. Kurikulum yang digunakan di sekolah dasar saat ini adalah kurikulum 2013 revisi 2016. Kompetensi yang diharapkan dalam kurikulum 2013 pada jenjang sekolah dasar/madrasah ibtidayah (MI) yaitu (1) menumbuhkan sikap religius dan etika sosial yang tinggi dalam kehidupan bermasyarakat, berbangsa dan bernegara, (2) menguasai pengetahuan, dan (3) memiliki keterampilan atau kemampuan menerapkan pengetahuan dalam rangka melakukan penyelidikan ilmiah, pemecahan masalah, dan pembuatan karya kreatif yang berkaitan dengan kehidupan sehari-hari (Kemendikbud, 2016). Berdasarkan temuan di atas serta tuntutan pencapaian kompetensi dalam kurikulum 2013, maka peneliti mengembangkan modul pembelajaran yang berpendekatan Discovery Learning yang belum ditemukan dalam pembelajaran Sains SD.

\section{Fase Pengembangan}

Berdasarkan informasi yang didapatkan pada studi pendahuluan, kemudian peneliti membuat desain modul Discon pada pembelajaran praktikum Sains SD. Modul yang dikembangkan adalah modul untuk kegiatan yang memuat kompetensi percobaan. Berdasarkan analisis kurikulum di kelas IV SD, maka materi yang memuat kegiatan percobaan adalah materi (a) gaya dan gerak, (b) sumber energi dan perubahan bentuk energi, (c) bunyi dan pendengaran, (d) cahaya dan penglihatan. Modul yang disusun diberi nama "Modul Discon Pembelajaran Praktikum IPA Kelas IV $S D$ " Discon merupakan akronim dari Discovery Learning. Modul ini berisi komponen (a) judul, (b) kata pengantar, (c) daftar isi/tabel/gambar, (d) petunjuk penggunaan, (e) kompetensi inti, kompetensi dasar, tujuan pembelajaran, (f) peta konsep, (g) materi, (h) kegiatan percobaan yang berisi tujuan, peralatan percobaan, langkah kerja, dan analisi hasil praktikum, kesimpulan (i) rangkuman, (j) tes formatif, (k) kunci jawaban, (l) pedoman penskoran, (m) tindak lanjut, (n) harapan, (o) glosarium, dan (p) daftar pustaka. Setalah draft Modul Discon selesai disusun, maka selanjutnya melakukan uji validasi dan uji kepraktisan. Berikut dijelaskan hasil dari uji validasi dan uji kepraktisan.

a. Uji Validitas Modul Discon

Validasi modul didasarkan dua aspek penilaian yaitu aspek isi materi dan aspek penyajian pembelajaran dalam modul. Jumlah total pernyataan sebanyak 13 item, dengan menggunakan penilaian skala 5. Adapun hasil penilaian dari para ahli tersaji dalam tabel berikut:

Tabel 4. Hasil Validasi Ahli

\begin{tabular}{lccc}
\hline Validator & Skor & Rata2 & Kualitatif \\
\cline { 1 - 2 } Ahli 1 & 51 & \multirow{2}{*}{50,5} & Valid \\
\cline { 1 - 2 } Ahli 2 & 50 & & \\
\hline
\end{tabular}

Berdasarkan hasil analisis instrumen validasi, maka didapatkan nilai dari Ahli 1 sebesar 51 dan nilai dari ahli 2 sebesar 50. Rata-rata perolehan nilai dari para ahli yaitu sebesar 50,5. Apabila dimasukan dalam kriteria penilaian untuk mendapatkan data kualitatif, maka nilai tersebut masuk kriteria valid.
Dari hasil analisis perolehan nilai tersebut, menggambarkan bahwa nilai rata-rata pada aspek isi materi sebesar $76,7 \%$ dan aspek penyajian pembelajaran sebesar $78,6 \%$. Selengkapnya hasil penilaian aspek validasi modul tersaji dalam grafik $1 \mathrm{di}$ bawah ini. 


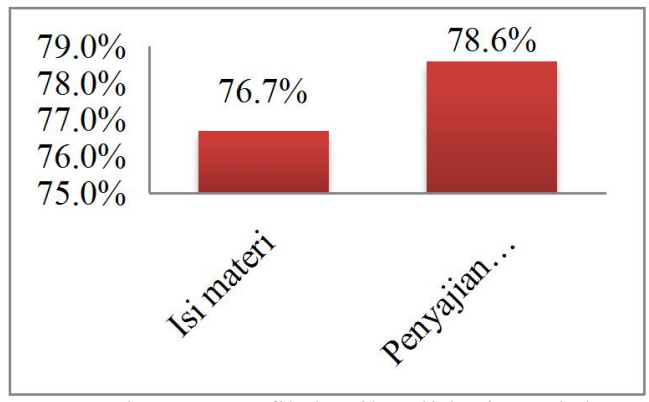

Gambar 1. Grafik hasil validasi modul

Dengan kriteria ini maka modul yang dikembangkan layak untuk diujicobakan. Adapun saran dari para ahli yaitu (1) menambahkan contoh atau ilustrasi dari sajian materi dan (2) menambahkan gambar pada langkah kerja atau prosedur percobaan agar siswa tidak mengalami kesulitan dalam mengikuti prosedur percobaan yang disiapkan.

b. Uji Kerpaktisan Modul Discon

Setelah modul dinyatakan valid oleh para ahli, maka langkah selanjutnya melakukan ujicoba terbatas. Ujicoba ini dimaksudkan untuk mengetahui kepraktisan penggunaan modul oleh peserta didik atau sasaran belajar. Subjek yang terlibat dalam ujicoba terbatas sebanyak 15 siswa dari 3 sekolah. Aspek penilaian dalam uji kepraktisan yaitu (a) efektif, (b) interaktif, (c) menarik, (d) efisien, dan (e) kreatif. Jumlah pernyataan dari kuesioner kepraktisan sebanyak 15 butir. Dari analisis hasil kuesioner tersebut diperoleh nilai sebesar 63,80 dengan kategori sangat praktis. Hasil analisis uji kepraktisan untuk setiap aspek digambarkan seperti berikut.

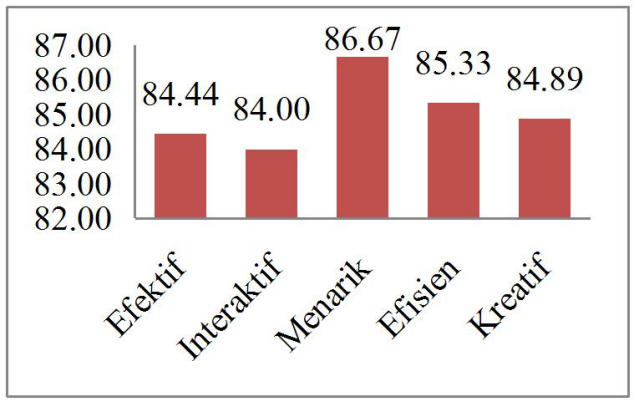

Gambar 2. Grafik hasil kepraktisan modul

Berdasarkan gambar di atas, diperoleh nilai aspek efektif sebesar 84,44. Nilai aspek interaktif sebesar 84,00. Nilai aspek menarik sebesar 86,67. Nilai aspek efisien sebesar 85,33. Nilai aspek kreatif sebesar 84,89 . Hasil tersebut bermakna bahwa modul Discon Pembelajaran Praktikum Sains SD praktis digunakan oleh siswa SD.

\section{Fase Penilaian}

Setelah modul dinyatakan praktis, maka langkah selanjutnya melakukan ujicoba lapangan luas. Ujicoba ini bertujuan untuk mencari keefektifan modul Discon. Setelah dilakukan ujicoba pada 110 siswa dari 3 sekolah didapatkan hasil sebagai berikut:

Tabel 5. Rekapitulasi hasil ujicoba besar

\begin{tabular}{cccc}
\hline $\begin{array}{c}\text { Rata-rata } \\
\text { pretes }\end{array}$ & $\begin{array}{c}\text { Rata-rata } \\
\text { postes }\end{array}$ & n-gain & kategori \\
\hline 62,9 & 89,1 & 0,71 & Tinggi \\
\hline
\end{tabular}

Dari tabel di atas, diperoleh nilai rata-rata pretes sebesar 62,9 dan rata postes sebesar 89,1 . Sesuai dengan rumus N-Gain yang dikemukakan sebelumnya, maka didapatkan nilai n-gian sebesar 0,71 . Berdasarkan tabel 3, maka kategori modul yang dikembangkan masuk pada kategori tinggi atau sangat efektif. Hal ini menandakan bahwa modul Discon Pembelajaran Praktikum Sains Kelas IV SD memiliki keefektifan yang tinggi.

Melalui tahapan pengembangan yang telah dilakukan dapat disimpulkan bahwa Modul Discon Pembelajaran Praktikum Sains 
Kelas IV SD yang telah dikembangkan merupakan salah satu bahan ajar yang dapat dijadikan referensi dalam pembelajaran Sains. Modul ini memiliki beberapa kelebihan yaitu (1) dapat membantu guru dalam menyampaikan materi pembelajaran kepada siswa sehingga memudahkan peran guru sebagai fasilitator. Hal sesuai dengan J.Richard Suchman. Menurutnya, untuk dapat memberikan suasana yang tidak menghukum dan menstimulasi anak-anak terlibat dalam pembelajaran yang menyenangkan, menarik, dan memuaskan diri maka tugas guru sebagai fasilitator adalah memberikan siswa lingkungan yang responsif terhadap kebutuhan siswa, sehingga mereka dapat mencoba berbagai hal tanpa rasa takut atas hukuman yang diberikan. (2) siswa dapat membangun pengetahuannya sendiri melalui analisis hasil percobaan sehingga dapat dikatakan pembelajaran menjadi bermakna. Pembelajaran lebih bermakna berhubungan dengan retensi memori yang lebih baik sehingga dapat mengaplikasikan hasil pembelajaran tersebut pada situasi yang baru. Hal ini sejalan dengan pendapat Robet Glaser, yaitu pengetahuan yang diperoleh dari hasil penyelesaian masalah lebih mudah diaplikasikan pada situasi yang baru. (3) siswa dengan mandiri dapat mempelajari materi Sains. Melalui modul yang berpendekatan Discovery Learning siswa mudah melakukan percobaan-percobaan sampai pada membuat kesimpulan sendiri. Dalam modul Discon disediakan petunjuk penggunaan serta prosedur melakukan percobaan. Analisis hasil praktikum sebagai bagian dari Discovery learning menuntun siswa untuk dapat membuat kesimpulan atau menyelesaikan masalahnya sendiri. Hal ini sesuai dengan pendapat Bruner yaitu Discovery Learning membantu siswa menjadi lebih otonom, mandiri, dan bertanggung jawab untuk pembelajaran yang mereka lakukan. (4) meningkatkan rasa ingin tahu siswa akan fenomena alam atau permasalahan yang terjadi dalam kehidupan sehari-hari. Hal ini sejalan dengan konservasi memori atau transfer of training oleh Bruner. Menurut Bruner semakin banyak latihan memecahkan atau mencari solusi atas masalah yang diberikan kepada siswa, maka besar kemungkinan siswa dapat memecahkan masalah pada situasi atau masalah baru. dan (5) menumbuhkan motivasi belajar siswa pada sains. Menurut Bruner Siswa akan menjadi lebih termotivasi ketika mereka belajar dengan menemukan sesuatu sendiri, daripada hanya mendengar tentang hal itu. Siswa diberikan kebebasan cara memecahkan masalah. Kebebasan ini merupakan Reward bagi anak dalam penemuan itu sendiri. Kepuasan bagi mereka adalah jika dapat memecahkan masalah sendiri.

Hasil pengembangan Modul Diskon Pembelajaran Sains di Kelas IV SD sebagai berikut:

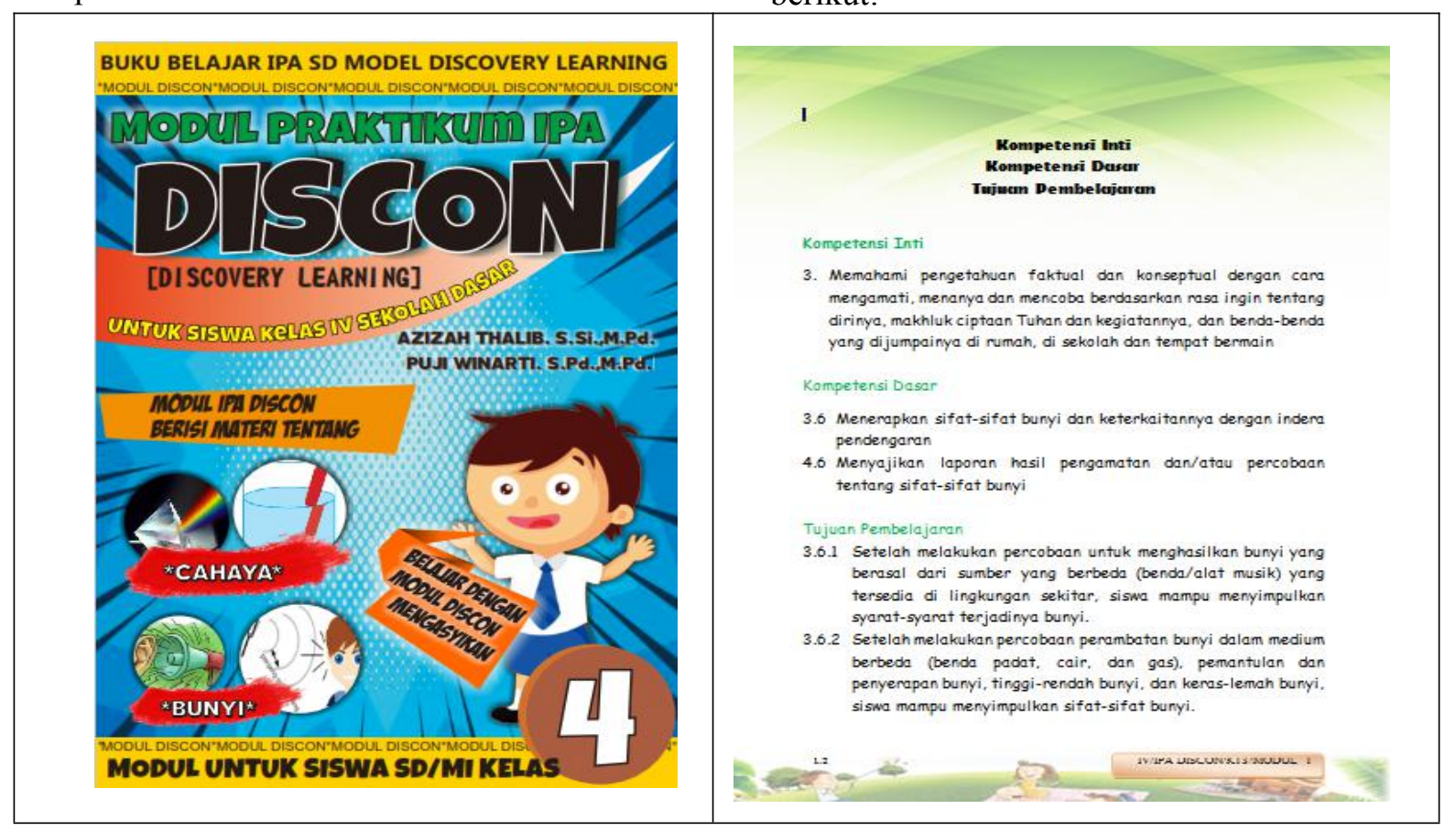




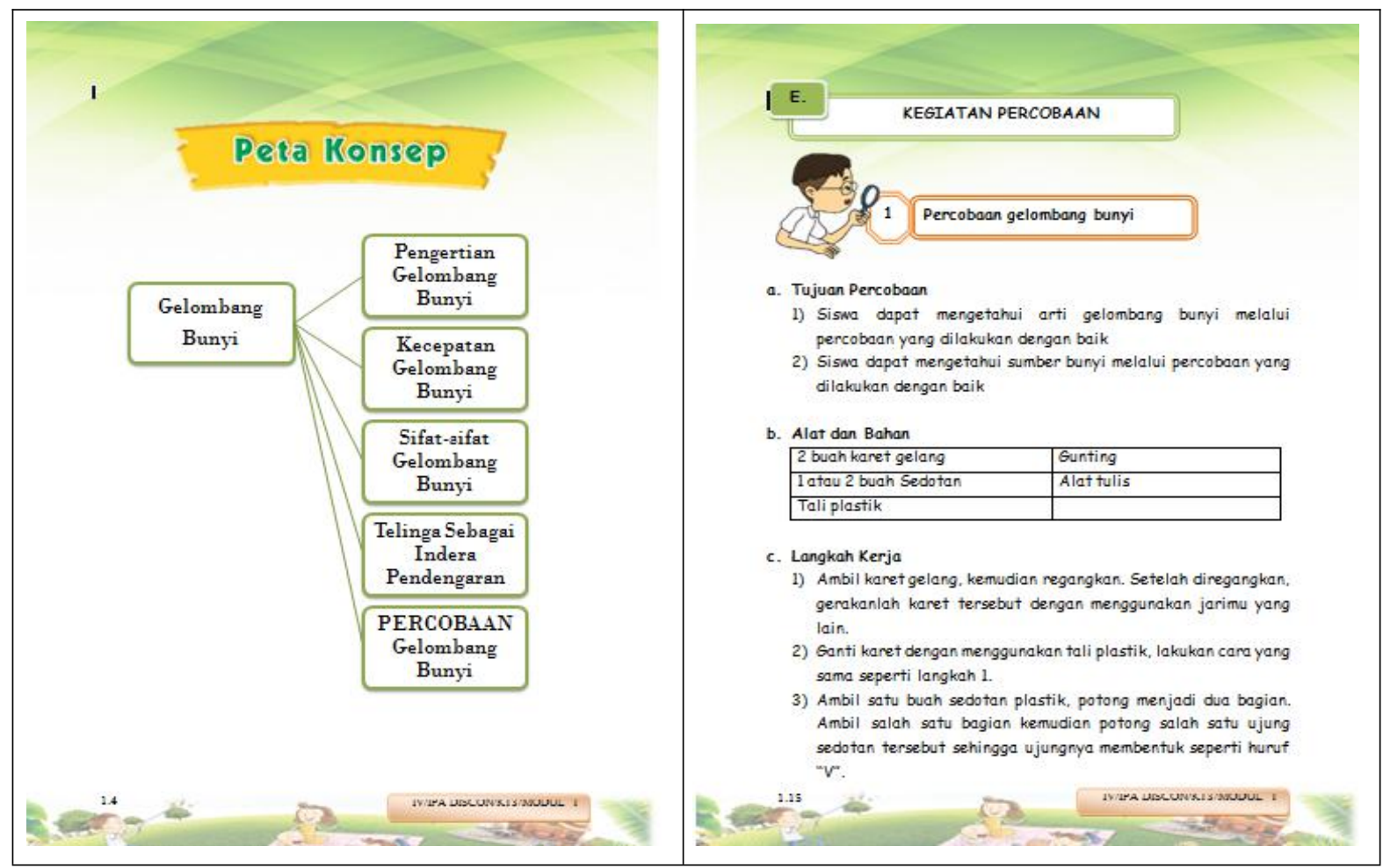

Gambar 3. Contoh hasil pengembangan modul Discon

\section{KESIMPULAN \& SARAN}

Kesimpulan yang diperoleh dalam penelitian ini adalah:

1. Modul Discon sains di Kelas IV sekolah dasar merupakan salah satu bahan ajar mandiri yang dapat membantu siswa memahami materi sains. Modul ini memiliki komponen sesuai dengan karakteristik bahan ajar mandiri. Komponen tersebut yaitu: (a) Judul (b) petunjuk penggunaan, (c) kompetensi inti, kompetensi dasar, tujuan pembelajaran, (d) peta konsep, (e) materi, (f) kegiatan percobaan yang berisi tujuan, peralatan percobaan, langkah kerja, dan analisi hasil praktikum, kesimpulan (g) rangkuman, (h) tes formatif, (i) kunci jawaban, (j) pedoman penskoran, (k) tindak lanjut, (1) harapan, (m) glosarium, dan (n) daftar pustaka.

2. Modul Discon sains di Kelas IV sekolah dasar yang dikembangkan telah memenuhi keriteria valid, praktis, dan efektif. Nilai kevalidan sebesar 50,5 dengan keriteria valid. Nilai kepraktisan sebesar 63,80 dengan kategori sangat praktis. Nilai keefektifan sebesar 0,71 atau dengan kategori sangat efektif. Berdasarkan perolehan hasil ini, maka dapat dikatakan bahwa modul ini dapat digunakan sebagai alat bantu dalam pembelajaran sains di jenjang sekolah dasar.

Berdasarkan hasil penelitian yang diperoleh, maka dapat dikemukakan beberapa hal sebagai saran perbaikan, yaitu:

1. Agar dapat mencapai kompetensi pembelajaran sains seperti yang tertuang dalam kurikulum, maka guru sebaiknya menggunakan berbagai metode yang dapat menumbuhkan motivasi belajar siswa dalam mempelajari sains. Salah satu metode yang dapat digunakan yaitu metode discovery learning.

2. Peran guru sebagai fasilitator dapat terbantukan penggunaan bebagai bahan ajar sehingga pembelajaran dapat berjalan dengan efektif dan interaktif. Salah satu bahan ajar yang dapat dipergunakan guru dalam menyampaikan pembelajaran yaitu dengan penggunaan modul khususnya dalam pembelajaran sains

\section{DAFTAR PUSTAKA}

Alfiriani, A., \& Hutabri, E. (2017). Kepraktisan dan Keefektifan Modul Pembelajaran Bilingual Berbasis Komputer. Jurnal Kependidikan , 1 (1), 12-13. 
Azizah, \& Winarti, P. (2016). Pengaruh Guided Discovery terhadap Hasil Belajar IPA Siswa Kelas IV SDN Gedanganak 01 Kecamatan Ungaran Timur Kabupaten Semarang. Jurnal Profesi Pendidikan Dasar , 3 (1), 1-10.

Carin, A. A. (1993). Teaching Science Through Discovery. New York: Macmillan Publishing Company.

Daryanto. (2013). Menyusun Modul: Bahan Ajar untuk Persiapan Guru dalam Mengajar. Yogyakarta: Gava Media.

Gillespie, H., \& Gillespie, R. (2007). Science for Primary School Teachers. New York: The McGraw Hill Companies.

Kemendikbud. (2016). Silabus Mata Pelajaran Sekolah Dasar/Madrasah Ibtidayah (SD/MI). Jakarta: Kementrian Pendidikan dan Kebudayaan.

Sani, R. A., Manurung, S. R., Suswanto, H., \& Sudiran. (2018). Penelitian Pendidikan. Tengerang: Tira Smart.

Sappe, A. (2013). Kemampuan Keterampilan Proses IPA Mahasiswa PGSD UPP Parepare. Jurnal Publikasi Pendidikan , III (1), 1-8.

Ward, H., Roden, J., Hewlett, C., \& Foreman, J. (2008). Teaching Science in the Primary Classroom. California: Sage Publications. 